\title{
An introduction to the United Kingdom balance of payments
}

\section{Introduction}

The balance of payments is one of the UK's key economic statistical series. It measures the economic transactions between United Kingdom residents and the rest of the world. It also draws a series of balances between inward and outward transactions, provides a net flow of transactions between UK residents and the rest of the world and reports how that flow is funded. Economic transactions include:

- exports and imports of goods, such as oil, agricultural products, other raw materials, machinery and transport equipment, computers, white goods and clothing

- exports and imports of services such as international transport, travel, financial and business services

- income flows, such as dividends and interest earned by foreigners on investments in the UK and by the UK investing abroad

- financial flows, such as direct investment, investment in shares, debt securities, loans and deposits

- transfers, which are offsetting entries to any one-sided transactions listed above, such as foreign aid and funds brought by migrants to the UK

The international investment position measures the levels of financial investment with the rest of the world, inward and outward.

\section{International statistical standards}

The Office for National Statistics (ONS) follows the international standards relating to balance of payments and international investment position statistics. There are several reasons for this. First, domestic and foreign analysts will be assured that the UK's official balance of payments and international investment position statistics comply with objective, coherent international standards that reflect current, global analytic needs. Second, the UK is a member of the international community and international users need comparable data for comparison between countries. Third, the UK, as a member of the European Union, as well as organisations such as the IMF and OECD, needs to compile its various economic statistics in conformity with standards set by those organisations. Fourth, the UK can compare and reconcile its data with those of other countries. Statistics need to be as comparable as possible in order to carry out this validation.

To facilitate such consistency and to provide guidelines for its members, the IMF issued the Balance of Payments Manual. The first edition appeared in 1948 and the most recent (fifth) edition in 1993. The conceptual framework of the UK balance of payments corresponds to that underlying the fifth edition of the IMF Manual, referred to as BPM5. BPM5 was implemented in the UK's balance of payments accounts and international investment position statistics in September 1998.

A process of reviewing the existing international standards started in the mid 1980s with the specific objective of harmonising, to the maximum extent possible, the statistical concepts, definitions, statistical units, classifications and terminology. 
Release of the revised standards started in 1993 with BPM5 and the third edition of the System of National Accounts (SNA93). BPM5 was prepared by the IMF in close co-operation with national compilers and with the Statistical Office of the European Communities, the OECD, the United Nations and the World Bank. Those five organisations jointly published SNA93. In 1995, the EU produced its own version of SNA93, the European System of Accounts (ESA95), upon which the UK's national accounts are based and which is consistent with BPM5. Both SNA93 and BPM5 were amended in 2000 to give more consistent guidance on the treatment of financial derivatives.

The United Nations Statistics Commission and the IMF Board of Directors have subsequently approved the comprehensive and parallel updating of the National Accounts and Balance of Payments manuals, in order to ensure their consistency and achieve greater harmonisation. ONS has developed the following webpage to inform users of progress and to invite their input:

www.statistics.gov.uk/about/Consultations/NA/default.asp

\section{Conceptual framework definitions}

\section{Balance of payments}

Broadly speaking, the UK balance of payments is a statistical statement designed to provide a systematic record of the UK's economic transactions with the rest of the world. It may be described as a system of consolidated accounts in which the accounting entity is the UK economy and the entries refer to economic transactions between residents of the UK and residents of the rest of the world (non-residents).

The balance of payments accounts are concerned not only with payments made but also any economic transactions during a period that give rise to a payment in an earlier or later period, for example, goods may change ownership in one period, though payment may be made in an earlier period (pre-payment) or in a later period (trade credit). They also include transactions for which there may never be a payment, for example, goods shipped under foreign aid or goods shipped between related enterprises. There is also more than one 'balance': the balance of payments is a system of accounts in which many balances can be derived, such as the balance of goods and services, the balance on current account, and the balance on capital and financial account.

Balance of payments statements cover a wide range of economic transactions which include:

(i) goods, services, income and current transfers; and

(ii) capital transactions, such as capital transfers; and

(iii) financial transactions involving the UK claims on, and liabilities to, non-residents.

Category (i) is shown in the current account, category (ii) in the capital account and category (iii) in the financial account.

\section{International investment position}

The UK's international investment position is a closely related set of statistics. It can be viewed as the balance sheet recording the UK's stock (or level) of foreign financial assets and liabilities at a particular date. The net international investment position is the difference between the stock of foreign financial assets and foreign liabilities at a particular date. 
Viewed more broadly, the international investment position can be shown as a reconciliation statement of the stock of investment at two different points in time by showing financial transactions and other changes (non-transaction changes) such as price changes, exchange rate variations and other adjustments that occurred during the period. Financial transactions which are included in the reconciliation statement are equivalent to the transactions measured in the financial account of the balance of payments. The ONS does not currently publish a full reconciliation of the international investment position showing price, exchange rate and other changes.

Classifications such as assets and liabilities, type of investment (direct, portfolio and other investment and reserve assets), and instrument of investment, are used consistently in both the balance of payments and the international investment position.

\section{Concepts of territory and residence}

In compiling the UK balance of payments and international investment position, the UK economy is conceived as comprising the economic entities that have a closer association with the territory of the UK than with any other territory. Each such economic entity is described as a resident of the UK. Any economic entity which is not regarded as a resident of the UK is described as a non-resident. The concept of residency is not based on nationality.

The UK's economic territory is defined to include the territories lying within its political frontiers and territorial seas, and in the international waters over which it has exclusive jurisdiction. It also includes its territorial enclaves abroad holding embassies, consulates, military bases, scientific stations, information or immigration offices, aid agencies etc., whether owned or rented by the UK governments with the formal agreement of the countries where they are located.

The UK offshore islands - Jersey, Guernsey and Isle of Man - are classified as nonresident to the UK. Thus transactions between UK residents and the islands are in the balance of payments, but transactions between islanders are not counted in the UK balance of payments. The islands are not part of the EU, so statistics relating to them are not required under ESA95 and they have to be excluded from the UK's economic territory to ensure full UK consistency with ESA95. This treatment is also technically consistent with BPM5 recommendations which states that 'In a maritime country, economic territory includes islands that belong to the country and are subject to the same fiscal and monetary authorities as the mainland; goods and persons move freely to and from the mainland and islands...'. The offshore islands are subject to their own fiscal authorities and have their own tax systems. Furthermore, there are impediments to taking up residency on the Channel Islands.

For balance of payments purposes, residents of an economy are generally deemed to have a centre of economic interest in the economy and to be resident for at least one year. The residents of the UK comprise:

- Resident general government institutions including the Scottish Parliament, Welsh Assembly, Northern Ireland Assembly and local government authorities and statutory bodies. The UK embassies, consulates, military establishments, etc. physically located abroad are included in the UK's economic territory and are therefore residents; similar entities of other countries physically located within the UK are outside the UK's economic territory and are therefore non-residents.

- Resident financial and trading enterprises which include all enterprises engaged in the production of goods and services on a commercial or equivalent basis within the territory of the UK. Enterprises may be incorporated or 
unincorporated; privately or government owned and/or controlled; and locally or foreign owned and/or controlled.

The definition of an enterprise in terms of the territory in which it is located often makes it necessary to divide a single legal entity into a head office operating in one economy and a branch operating in another economy. Resident enterprises include UK branches of foreign companies and exclude foreign branches of UK companies.

- Resident non-profit bodies, those in which individuals and/or enterprises combine, as owners, to produce goods and services within the territory of the UK for purposes other than to provide a financial return for themselves. Examples are churches, charitable organisations and representative business organisations such as Chambers of Commerce.

- Resident households and individuals which broadly encompass all persons residing in the territory of the UK for one year or more, whose general centre of economic interest is considered to be the UK. The UK's official diplomatic and consular representatives, the UK's armed forces, other UK government personnel stationed abroad and their dependants, UK students studying abroad, and UK patients being treated abroad are also included even though they may all be abroad for one year or more. They are treated as UK residents since their centre of interest is considered to be the UK. Generally, the centre of economic interest of persons visiting the UK for less than one year is considered to be outside the UK and they are therefore regarded as non-residents, but if they stay for one year or more they are considered to be residents for balance of payments purposes. Irrespective of their length of stay, non-residents also include foreign diplomatic, consular, military and other government personnel, their dependants, foreign students studying in the UK, and foreign patients being treated in the UK. If an individual maintains residences in the UK and another economy, they are considered to be UK residents if they typically spend more time in their UK residence than their foreign residence during the year. 


\section{Double-entry system}

\section{Rules for the UK double entry system}

Credit entries, changes in all economic resources provided by the UK to non-residents, including:

Exports of goods and services

Income accruing on the resources to UK from residents

Financial liabilities of the UK to non-residents

Transfers which are offsets to debit entries
Debit entries, changes in all economic resources received by the UK from non-residents, including:

Imports of goods and services

Income accruing on the resources to non-residents from UK

Financial claims of UK on non-residents

Transfers which are offsets to credit entries

Examples of UK double entry recording

Credits

Debits

1. Sales of goods (value 100) to non-residents for foreign exchange (i.e. goods provided and bank payment (a bank deposit) received in an account held abroad)

Goods 100 Bank deposits, foreign currency assets

2. Purchase of goods (value 120) from a non-resident using trade Credit (i.e. goods received and a claim on a resident (trade credit liability) provided)

Goods

Trade credit liabilities

3. Food aid (value 5) provided to non-residents (i.e. goods provided and transfer imputed)

Goods

5

Current transfers

4. payment of a loan (value 25) by a resident company to a non-resident lender (i.e. liability to a non-resident reduced and a reduction in bank deposits held abroad) Loan repayment

Bank deposits, foreign currency, assets 
Conceptually, an economic transaction has two sides: something of economic value is provided and something of equal value is received. The balance of payments reflects this in a double-entry recording system of credits and debits. When an economic value is provided (for example, UK exports a car) a credit entry is made, and when the corresponding economic value is received (for example, a payment for the car) a debit entry is made. For example, when an exporter sells (provides) goods to a nonresident, the exporter may receive cash (a financial asset) or another type of financial asset (for example, a trade credit claim) in return. The export is represented by a credit entry and the financial asset acquired is represented by an offset debit entry. Similar entries are made when an importer buys a car (debit) and pays for it (credit). So a credit entry represents a change in rest of world ownership of any sort of UK asset (real or financial); a debit entry represents a change in UK ownership of rest of world assets.

An understanding of the double-entry recording system is necessary for a complete understanding of balance of payments statistics.

Under the double-entry system, by definition credit entries must equal debit entries. Credit entries are required for exports of goods and services, income receivable, and changes in financial liabilities. Likewise, debit entries are required for imports of goods and services, income payable, and changes in financial assets. Where something of economic value is provided without something of economic value in exchange (that is, without a quid pro quo) the double-entry system requires an offset to be imputed (a transfer entry) of equivalent value. For example, food exported as aid requires a credit entry for the goods provided and a debit transfer as the aid offset.

\section{Sign convention in the UK balance of payments statistics}

The sign convention used in presenting the UK balance of payments statistics is to give a positive sign to an increase in either credit or debit entries and a negative sign to a decrease in credit or debit entries. Balances (calculated as credits less debits) or items which are net credits have no sign, while balances which are net debits have a negative sign.

When considering making international comparisons it should be borne in mind that there is no unique or correct sign convention and other countries/institutions use variations. In particular the convention used by the IMF in their publications gives no sign to credit entries and a minus sign to all debit entries (for example, imports and acquisitions of assets).

\section{Errors and omissions}

It follows that, in principle, under a double-entry accounting system, the difference between the sum of credit and debit entries must be zero. In practice, some transactions are not measured accurately (that is, errors) and some are not measured at all (that is, omissions). Data sources used to compile the accounts often measure the credit and debit sides from different data sources and may not always do so consistently. There could be many reasons why these sources may not measure the acquisition side of the transaction and the corresponding payments, either in the same accounting period or at the same value. To restore the equality of credit and debit entries, a net errors and omissions item is included in the balance of payments accounts. The item indicates whether credit or debit transactions would be needed to balance the accounts, but does not show where the discrepancy lies. Usually the financial account is considered to be the most likely source. 


\section{Valuation}

It is important that the balance of payments and international investment position statistics carry values that have economic meaning to enable useful analysis, and to provide meaningful indicators of cross-border economic activity. It is also important for the double-entry accounting system that a uniform valuation is adopted. This means that the credit and debit entries of each transaction - which in practice may be derived from independent sources - should be valued at the same price. In addition, a uniform valuation is essential to sum different types of transactions on a consistent and comparable basis. The use of a uniform valuation principle aids understanding by users. Moreover, statistics for different countries will not be comparable unless both parties to a transaction adopt the same valuation principle. It is also important to use a principle which is consistent with national accounting principles. For all these reasons, market price is used in UK economic statistics for valuing transactions.

Market price is the amount of money that a willing buyer pays to acquire something from a willing seller, when such an exchange is between independent parties and involves only commercial considerations. In practice, one or more of the conditions needed to establish a market price may be absent and other valuations may be used.

For the most part, the price at which a transaction is recorded in the accounts of the transactors or in the administrative records used as data sources will be the market price or a very close approximation of it. This valuation is known as the transactions price and is the practical valuation basis used in the balance of payments, both because it aids consistent recording of credits and debits and because of its usual proximity to the ideal market valuation. The following paragraph discusses a special case of transactions where market prices may not apply, namely transfer pricing between affiliated enterprises in different countries.

\section{Transfer pricing}

Where transactions are between affiliated enterprises in different countries, the prices adopted in their books for recording transactions in goods and services and any associated indebtedness and interest - referred to as transfer prices - may not correspond to prices that would be charged to independent parties. There will be some departure from the market price principle if transfer prices are different from those charged to enterprises outside the group. However there are practical difficulties in identifying and suitably adjusting individual cases. Transfer pricing to avoid tax is illegal in the UK so the distortions in the international accounts caused by transfer pricing are not considered widespread. For both reasons, adjustments to account for transfer pricing are rarely made in practice.

\section{Assets and liabilities}

As with all international investment position statistics, foreign financial assets and liabilities should, in principle, be valued at their current market price at the reference date. In practice this is not always possible and valuation guidelines are adopted in order to approximate market valuation, particularly for those financial assets and liabilities that are only rarely transacted. For example, in measuring the value of direct investment in equity capital, much of which is never traded or is traded infrequently, market value is approximated by one of the following methods: a recent transaction price; directors' value; or net asset value. Over time, this is likely to underestimate the true market value of Foreign Direct Investment. 


\section{Unit of account and conversion}

Transactions and stock positions originally denominated in foreign currencies need to be converted to pounds sterling using market rates of exchange prevailing at the time of the transaction (balance of payments) or at the reference date (international investment position). Transactions should be converted at the mid-point of the buying and selling exchange rates applying at the time of transaction. Stocks should be converted at the mid-point of the buying and selling exchange rates applying at the beginning or end of the period. In practice, the actual rate used varies according to the source of the transaction or stock data.

\section{Time of recording}

\section{Transactions}

The time of recording of transactions in balance of payments and international investment position statistics is, in principle, the time of change of ownership (either actual or imputed). Under the double-entry system, both sides of a transaction should be recorded in the same period. This is consistent with the principle of accrual accounting, which requires that transactions be recorded when economic value is created, transformed, exchanged, transferred or extinguished.

Change of ownership is considered to occur when legal ownership of goods changes, when services are rendered and when income accrues. In the case of transfers, those which are imposed by one party on another, such as taxes and fines, should ideally be recorded at the moment at which the underlying transactions or other flows occur which give rise to the liability to pay; other transfers should be recorded when the goods, services etc. change ownership.

For financial transactions, the time of change of ownership is taken to be the time when transactions are entered in the books of the transactors. That is taken to be the time when a foreign financial asset or liability is acquired, relinquished by agreement, sold or repaid. The commitment or pledging of an asset does not constitute an economic transaction, and no entry should be shown unless a change of ownership actually occurs in the period covered. Likewise, the entries for loan drawings should be based on actual disbursements and not on commitments or authorisations. Entries for loan repayments should be recorded at the time they are due rather than on the actual payment date.

Both sides of a transaction should be recorded in the same period. In practice the time of recording of transactions in the balance of payments and international investment position statistics will reflect the practices in data sources, and may diverge from the principle of time of change of ownership. For the UK, transactions in goods credits (exported goods) are mainly recorded at the time when goods are shipped as this is assessed to be a generally good practical approximation of the time when ownership changes. Goods debits (imported goods) are recorded when customs records relating to the movement of the goods across the frontier are processed, again in the expectation that this is the best practical approximation to change of ownership that can be generally achieved. For the remainder of the current account, the time of the recording of transactions generally complies with the time of change of ownership. Exceptions occur mainly because the record-keeping practices of some data providers may not be on this basis. Financial account transactions usually are recorded appropriately, that is, when the parties record transactions in their books. However, some transactions may be derived from information supplied by intermediaries that are not party to the transactions and may not be aware of the time of change of ownership. Also, some enterprises may adopt accounting practices 
that lead to inconsistent time of recording; a simple example is that different enterprises may close off their accounts at different times of day.

\section{Stock}

The time of recognising the stock of a foreign financial asset or liability follows naturally from the time of recording of a transaction in that asset or liability. For example, if a transaction is undertaken to acquire a foreign financial asset, there will also be a consequential increase in the stock of foreign financial assets at the end of that period. Of course, if the asset is disposed of before the end of the period, it will not contribute to the stocks statistics to be recorded for the period, but the disposal will have given rise to another transaction to be recorded for the period.

\section{Types of transactions in the balance of payments}

An economic transaction occurs when something of economic value is provided by one party to another. Transactions that are considered to have economic value comprise those in goods, services, income and financial assets and liabilities. The transactions recorded in a balance of payments statement stem from dealings between two parties, one being a resident and the other a non-resident. The types of transactions included in the balance of payments are exchanges, one-sided transactions and imputed transactions.

\section{Exchanges}

Exchanges are the most important and numerous type of transaction. They include transactions in which one transactor provides something of economic value to another transactor and receives in return something of equal value.

\section{Special cases of imputation/estimation}

\section{Migrants' transfers}

A special statistical treatment is required when a person migrates, that is when the person's status changes from non-resident to resident (or vice versa). When this change occurs, the property owned by the migrant becomes the property of a resident instead of that of a non-resident (or vice versa). This change of ownership of net worth between economies is included in the balance of payments. For example, any financial assets held abroad by the migrant become claims by the UK on the rest of the world.

Offset entries are made corresponding to the transfer of net worth and, by their nature, these are included as transfers in the capital account. This treatment amounts to envisaging a transfer of property from the person in their capacity as a non-resident to the person in their capacity as a resident (or vice versa). In principle, this transaction embraces all the migrant's property, whether or not it accompanies the migrant.

\section{Reinvested earnings}

A number of special cases of imputed transactions feature in balance of payments compilation. One case involves the reinvestment of earnings in resident enterprises by their non-resident direct investors. These reinvested earnings are regarded as being paid out as investment income and then reinvested in the enterprises from which they originated. They are therefore recorded both as a component of investment income in the current account and as a component of direct investment in the financial account. It is considered analytically useful to identify these transactions separately in economic statistics because of the substantial contribution they make to the stock of direct investment finance in a country. 


\section{Financial services}

A further case relates to estimation for the implicit fees associated with financial services. These include spread earnings on foreign exchange, derivatives and securities trading and FISIM, which is the implicit margin resulting from interest rate differentials between borrowing and lending.

\section{Exceptions to change of ownership}

In economic statistics, transactions are considered to occur when the goods and financial assets change ownership between transactors, when services are provided by one transactor to another, or when income is earned by one transactor from another. However, there are certain situations in which no change of ownership legally occurs, but where transactions are nonetheless considered to have occurred for balance of payments purposes. The situations include financial leases, goods imported into or exported from the UK for processing and return, and transactions between a head office in one country and a branch in another.

\section{Financial leases}

A financial lease is regarded as a method of obtaining all the rights, risks and rewards of ownership of real resources without holding legal ownership. Although legal ownership remains with the lessor during the term of the lease, all the risks and responsibilities apply to the lessee. In these cases, the basic nature of the transaction is given precedence over its legal form, by imputing a change of ownership of the resource to the lessee. As a result of this imputation, a financial liability is recognised and lease payments are classified as partly loan repayments in the financial account and partly interest in the current account, rather than as services in the current account.

\section{Goods for processing}

In economic statistics, the value of goods entering or leaving the UK for processing and returning to the country of origin after processing should be recorded on a gross basis, that is, recording the goods both when they enter (as imports) and when they leave (as exports), even though there is no legal change of ownership of those goods. Thus a good entering the UK to be processed and returned to the country of origin is recorded as an import at the appropriate value and subsequently as an export recorded by the customs system at the original value plus the added value of the processing. A symmetrical treatment should be applied to UK goods exported for processing and return. The basis for this treatment is that such goods lose their identity during processing by being transformed or incorporated into different goods. On the other hand, for goods undergoing repairs only the value of the repair, not the gross value of the goods, is included in the goods credits or debits.

\section{Branches}

In economic statistics, it is usually necessary to split the activities of a legal entity and recognise two units, a head office in one country and a branch in another. Flows of goods, services, income and finance between the branch and its head office are therefore treated as transactions, even though they are legally part of the same unit. For example, goods and services sent from the head office to its branch are to be treated as exports of goods and services by the head office.

There are two cases where such splitting becomes necessary. The first occurs when production of goods and services is undertaken by the personnel, plant and equipment of the legal entity in an economic territory outside the economic territory 
of the head office, provided certain conditions apply. These conditions include: the intention to operate in the separate economy indefinitely or over a long period ( 12 months is used as a rule of thumb); keeping a set of accounts of the branch's activity (that is, income statement, balance sheet, transactions with the parent entity); eligibility to pay income tax in the host country; having a substantial physical presence; and receiving funds for the branch's work which are paid into its own bank account.

The second case occurs when a person or legal entity resident in one economy owns land and buildings located in another economy. Ownership of immovable assets is always attributed in balance of payments and international investment position statistics to residents of the economy in which the assets are located. Thus land in the domestic territory, which is in fact owned by a non-resident, is treated as being owned by a notional resident entity, which in turn has a foreign direct investment liability to the real owner. It should also be recalled that the territorial enclaves associated with embassies, military bases etc. are regarded as part of the economic territory of the economy they represent. When these institutions buy and sell the land in these enclaves they are effectively adding to and subtracting from the economic territory of their government. Such transactions in land owned by foreign embassies are recorded in the capital account as the acquisition/disposal of non-produced, non-financial assets.

\section{Other changes in the international investment position}

In addition to the financial transactions included in the balance of payments, the international investment position reconciliation statement includes the other changes which contribute to differences between opening and closing positions for a period.

Other changes in position may occur through price changes, exchange rate changes and other adjustments. Price changes are valuation changes that occur because of changes in the market price of a financial instrument, such as a change in the price of a share or debt security, or through revaluing a company's net worth.

Exchange rate changes are due to fluctuations in the value of the pound, in which the accounts are compiled, relative to the currencies in which foreign assets and liabilities are denominated.

Other adjustments can arise from a number of causes such as write-off of bad debts, classification changes, monetisation/demonetisation of gold, and the allocation/ cancellation of Special Drawing Rights. A reclassification would occur where a foreign investor's equity investment in an enterprise increased during the reporting period and the increase was sufficient to change the classification of the investor's total equity holding at the end of the period from portfolio investment to direct investment. Monetisation of gold occurs when the Bank of England monetises commodity stocks of gold and adds these to its monetary gold holdings as part of the UK's official reserve assets. Special Drawing Rights in the IMF are also included in the UK's official reserve assets. Allocations and cancellations of these instruments are included as other adjustments.

\section{Gross and net recording}

Entries for current and capital account items are generally treated so that credits for each component are recorded separately from debits. Current and capital account transactions, in this context, are described as being recorded gross.

Gross recording contrasts to the recording of transactions in the financial account, which is mainly on a net basis, although for long-term trade credits and loans, gross drawings and repayments are included in the financial account. The net recording of 
other financial account items means that, for each item, credit transactions are combined with debit transactions to arrive at a single result - either a net credit or net debit - reflecting the net effect of all increases and decreases in holdings of that type of asset or liability during the recording period. There are several types of netting in the financial account, for example, the netting of purchases and sales within an instrument in an asset position, and netting of assets and liabilities as in the case of direct investment.

\section{Standard balance of payments classification}

Balance of payments and international investment position statistics need to be arranged in a coherent structure to facilitate their use and adaptation for purposes such as policy formulation, analytical studies, projections, bilateral comparisons, and regional and global aggregations. BPM5 contains a standard classification and list of standard components of the balance of payments and international investment position. These standards were developed taking into account the views of national compilers and analysts, and the requirement to harmonise concepts and definitions with related international statistical standards and classifications. The classification also reflects the separation of categories that may exhibit different economic behaviour, may be important in a number of countries, are readily collectable, and are needed for harmonising with other bodies of statistics.

The standard balance of payments classification comprises two main groups of accounts - the current account and the capital and financial account. Transactions classified to the current account include goods and services, income and current transfers. Within the capital and financial account, the capital account includes capital transfers and the net acquisition or disposal of nonproduced, non-financial assets. The financial account includes transactions in financial assets and liabilities.

Transactions in current account and capital account items are generally shown on a gross basis (gross debits and credits separately). Transactions in financial account items are mainly recorded on a net basis.

\section{Current account}

Table A (opposite) shows the standard classification of the current account. Each of the broad categories is described briefly below, while individual component items are described in detail in subsequent chapters.

Goods and services are divided into separate accounts for goods and services Goods comprise most movable goods that change ownership between UK residents and non-residents.

Services comprise services transactions between UK residents and non-residents, together with some transactions in goods where, by international agreement, it is not practical to separate the goods and services components (for example, goods purchased by travellers are classified to services).

Income refers to income earned by UK residents from non-residents and vice versa. Income covers compensation of employees and investment income. Compensation of employees comprises wages, salaries and other benefits earned by individuals from economies other than those in which they are residents, as well as earnings from extraterritorial bodies such as foreign embassies, which often employ staff from the economy in which they are located. Investment income comprises income earned from the provision of financial capital and is classified by direct, portfolio and other investment income and income earned on the UK's reserve assets. 


\section{Summary of balance of payments in 2007}

\begin{tabular}{|c|c|c|}
\hline & Credits & Debits \\
\hline \multicolumn{3}{|l|}{ 1. Current account } \\
\hline A. Goods and services & 368337 & 415817 \\
\hline B. Income & 285745 & 277139 \\
\hline $\begin{array}{l}\text { 1. Compensation of employees } \\
\text { 2. Investment income } \\
2.1 \text { Direct investment } \\
\text { 2.2 Portfolio investment } \\
2.3 \text { Other investment (including earnings on reserve assets) }\end{array}$ & $\begin{array}{r}1159 \\
284586 \\
84765 \\
66254 \\
133567\end{array}$ & $\begin{array}{r}1824 \\
275315 \\
51334 \\
66546 \\
157435\end{array}$ \\
\hline C. Current transfers & 15665 & 29359 \\
\hline $\begin{array}{l}\text { 1. Central government } \\
\text { 2. Other sectors }\end{array}$ & $\begin{array}{r}4244 \\
11421\end{array}$ & $\begin{array}{l}14061 \\
15298\end{array}$ \\
\hline Total current account & 669747 & 722315 \\
\hline \multicolumn{3}{|l|}{ 2. Capital and financial accounts } \\
\hline A. Capital account & 4589 & 1948 \\
\hline $\begin{array}{l}\text { 1. Capital transfers } \\
\text { 2. Acquisition/disposal of non-produced, non-financial assets }\end{array}$ & $\begin{array}{r}3810 \\
779\end{array}$ & $\begin{array}{r}1189 \\
759\end{array}$ \\
\hline B. Financial account & 1020548 & 980718 \\
\hline $\begin{array}{l}\text { 1. Direct investment } \\
\text { Abroad } \\
\text { 1.1. Equity capital } \\
\text { 1.2. Reinvested earnings } \\
\text { 1.3. Other capital } \\
\text { In United Kingdom } \\
\text { 1.1. Equity capital } \\
\text { 1.2. Reinvested earnings } \\
\text { 1.3. Other capital| }\end{array}$ & $\begin{array}{r}111343 \\
78072 \\
33118 \\
153\end{array}$ & $\begin{array}{r}130335 \\
130335 \\
56464 \\
54296 \\
19575\end{array}$ \\
\hline $\begin{array}{l}\text { 2. Portfolio investment } \\
\text { Assets } \\
\text { 2.1. Equity securities } \\
\text { 2.2. Debt securities }\end{array}$ & 175172 & $\begin{array}{l}96957 \\
96957 \\
30824 \\
66133\end{array}$ \\
\hline $\begin{array}{l}\text { Liabilities } \\
\text { 2.1. Equity securities } \\
\text { 2.2. Debt securities }\end{array}$ & $\begin{array}{l}175172 \\
-16272 \\
191444\end{array}$ & \\
\hline $\begin{array}{l}\text { 3. Financial derivatives (net) } \\
\text { 4. Other investment } \\
\text { Assets } \\
4.1 \text { Trade credits } \\
4.2 \text { Loans } \\
4.3 \text { Currency and deposits } \\
\text { 4.4 Other assets }\end{array}$ & 734033 & $\begin{array}{r}19001 \\
733234 \\
733234 \\
-509 \\
225903 \\
506943 \\
897\end{array}$ \\
\hline $\begin{array}{l}\text { Liabilities } \\
\text { 4.1. Trade credits } \\
\text { 4.2. Loans } \\
\text { 4.3. Currency and deposits } \\
\text { 4.4. Other liabilities }\end{array}$ & $\begin{array}{r}734033 \\
- \\
46037 \\
687808 \\
188\end{array}$ & \\
\hline $\begin{array}{l}\text { 5. Reserve assets } \\
\text { 5.1. Monetary gold } \\
\text { 5.2. Special drawing rights } \\
\text { 5.3. Reserve position in the IMF } \\
\text { 5.4. Foreign exchange }\end{array}$ & & $\begin{array}{r}1191 \\
-50 \\
-188 \\
1450\end{array}$ \\
\hline Total capital and financial accounts & 1025137 & 982666 \\
\hline Total current, capital and financial accounts & 1694884 & 1704981 \\
\hline Net errors and omissions & 10097 & \\
\hline
\end{tabular}

1 Other capital transaction on direct investment abroad represents claims on affi-

liated enterprises less liabilities to affiliated enterprises

2 Other capital transactions on direct investment in the United Kingdom

represents liabilities to direct investors less claims on direct investors 
Transfers represent offsets to the provision of resources between residents and nonresidents with no quid pro quo in economic value (for example, the provision of food aid). Current transfers are distinguished from capital transfers, which are included in the capital account. Current transfers represent the offset to the provision of resources that are normally consumed within a short period (less than twelve months) after the transfer is made. In the example of food aid, the food is presumed to be consumed within twelve months of it being received. The classification of current transfers is by general government and other sectors.

\section{Capital account}

The capital account comprises both capital transfers and the acquisition and disposal of non-produced, non-financial assets (such as copyrights). The latter includes land purchases and sales associated with embassies and other extraterritorial bodies. Capital transfers entries are required where there is no quid pro quo to offset the transfer of ownership of fixed assets, or the transfer of funds linked to fixed assets (for example, aid to finance capital works), or the forgiveness of debt. It also includes the counterpart to the transfer of net wealth by migrants, referred to as migrants' transfers.

\section{Financial account}

The financial account comprises transactions associated with changes of ownership of the UK's foreign financial assets and liabilities. The main classifications used in the financial account are discussed in conjunction with the international investment position classification below.

The international investment position measures the UK's stock of external financial assets and liabilities, whereas the balance of payments financial account measures transactions in these assets and liabilities. Hence the classifications used in the financial account and international investment position need to be essentially the same.

\section{Major classifications of the financial account and international investment position}

Items in the financial account and international investment position statement are classified on a number of bases. The main ones are type of investment, assets and liabilities, instrument of investment, sector, and original contractual maturity of financial instruments.

A comparison of the international investment position statement and the balance of payments financial account shows one minor difference. In the category of direct investment in the financial account, reinvested earnings are shown separately whereas, in the international investment position statement, where no separate market price valuation of reinvested earnings can exist, the reinvested earnings are grouped into a composite category for equity and reinvested earnings.

\section{Type of investment}

The type of investment used in the UK's balance of payments and international investment position consists of five broad categories:

(i) Direct investment capital refers to capital provided to or received from an enterprise, by an investor in another country (that is, an individual, enterprise or group of related individuals or enterprises) who is in a direct investment relationship with that enterprise. A direct investment relationship exists if the investor has an equity interest in an enterprise, resident in another country, of 10 
per cent or more of the ordinary shares or voting stock. The direct investment relationship extends to branches, subsidiaries and to other businesses where the enterprise has significant shareholding.

(ii) Portfolio investment refers to transactions in equity and debt securities (apart from those included in direct investment and reserve assets). Debt securities comprise bonds and notes and money market instruments. In comparison with direct investment, it indicates investment where the investor is not assumed to have any appreciable say in the operation of the enterprise (for example, less than 10 per cent of the ordinary share or voting stock).

(iii) Financial derivatives cover any financial instrument the price of which is based upon the value of an underlying asset (typically another financial asset). Financial derivatives include options (on currencies, interest rates, commodities, indices, etc.), traded financial futures, warrants and currency and interest swaps. Under BPM5, transactions in derivatives are treated as separate transactions, rather than being included as integral parts of underlying transactions to which they may be linked as hedges. From 2005 onwards, financial derivatives comprise all UK banks' net derivative transactions. Prior to 2005, only estimates for the settlement receipts/payments on UK banks' interest rate swaps and forward rate agreements are included in financial derivatives.

(iv) Other investment is a residual category that captures transactions not classified to direct investment, portfolio investment, financial derivatives or reserve assets of the compiling economy. Other investment covers trade credits, loans (including financial leases), currency and deposits, and a residual category for any other assets and liabilities.

(v) Reserve assets refer to those foreign financial assets that are available to, and controlled by, the monetary authorities such as the Bank of England for financing or regulating payments imbalances. Reserve assets comprise: monetary gold, Special Drawing Rights, reserve position in the IMF, and foreign exchange held by the Bank.

\section{Assets and liabilities}

A financial asset is generally in the form of a financial claim on the rest of the world that is either represented by a contractual obligation (such as a loan) or is evidenced by a security (such as a share certificate). Two financial assets - monetary gold and Special Drawing Rights in the IMF - are not claims on the rest of the world. They are, however, included in international investment assets because they are readily available for payment of international obligations. A financial liability represents a financial claim of the rest of the world on the UK. Assets and liabilities in the international investment position statement are components of the balance sheet of an economy with the rest of the world. In the financial account the asset and liability classifications in essence reflect, respectively, transactions in claims on non-residents (assets) and in claims by non-residents (liabilities).

In the international investment position, the difference between assets and liabilities is the net international investment position, also referred to as the net liability position/net asset position, depending on the balance.

For direct investment, in both the financial account and international investment position, the main classification is by direction of investment, that is, direct investment abroad and direct investment in the UK. Direct investment abroad is derived by netting liabilities of the UK direct investors to their direct investment enterprises against claims on their direct investment enterprises abroad. Similarly, direct 
investment in the UK is derived after netting claims of the UK direct investment enterprises against their liabilities to those direct investors abroad.

\section{Instrument of investment}

Several instruments of investment are also identified. Some of these are only applicable to one type of capital, that is, the instrument reinvested earnings is only applicable to direct investment, while monetary gold and Special Drawing Rights are only used for reserve assets.

The major instruments and grouping of instruments identified in balance of payments and international investment statistics include:

- monetary gold

- $\quad$ Special Drawing Rights

- foreign exchange

- $\quad$ reserve position in IMF

- equity

- reinvested earnings

- debt securities

- financial derivatives

- $\quad$ trade credit

- loans

- currency and deposits

- $\quad$ other assets/liabilities

Holdings of financial derivatives data are presented as an annex to the international investment chapter.

Similar instruments may be combined into groups or combined with certain types of investment to make statistical presentations less cluttered.

For example:

- trade credit, loans, deposits, and other forms of finance including all debt securities, but excluding equity capital and reinvested earnings, between nonfinancial enterprises in a direct investment relationship, are combined and shown only as other direct capital. Similar aggregation applies to finance between a financial enterprise and a non-financial enterprise and between financial enterprises only in case of permanent debt

- bonds, bills, notes and money market instruments within portfolio investment are shown separately but under a heading of debt securities

- a number of financial assets, held as part of the UK's reserves assets (currency and deposits, bills, bonds, notes and money market instruments), are grouped under the category foreign exchange within the reserve assets category

\section{Foreign equity and debt}

At a broader level, instruments may be combined to show foreign equity and foreign debt. Foreign equity includes equity capital, reinvested earnings and equity securities. Foreign debt is a residual item containing all other instruments. They may be compiled 
on a gross basis (for example, foreign debt/assets and liabilities) or on a net basis (for example, net foreign debt).

\section{Sectorisation}

Transactor units within an economy may be grouped together into institutional sectors. Units within the same institutional sector may be expected to behave similarly in their financial and other dealings and in response to differing economic and political stimuli. The principle of classification by sector, or sectorisation, in the financial account and international investment position is to identify the sector of the domestic creditor for assets and the sector of the domestic debtor for liabilities.

Four sectors are generally distinguished in the standard components of the ONS balance of payments and international investment statistics: monetary financial institutions; central government; public corporations; and other.

Within the current and capital accounts, sectorisation is also applied to current and capital transfers, where a split between general government and other is used.

\section{Original contractual maturity}

The fifth edition of the balance of payments manual looks to distinguish between long-term or short-term investment. Investment longer than one year is deemed to be long-term and investment less than one year is deemed to be short-term.

\section{Other financial classifications}

Other classifications in the financial account and international investment position include the domicile of liabilities issued by residents, drawings and repayments for long-term liabilities in the form of both trade credits and loans and the currency of assets and liabilities.

\section{Country classification}

The general principles applying to the compilation of a global balance of payments statement for the UK can be applied to the preparation of a statement for the UK's transactions with an individual country or a group of countries.

\section{Reliability of estimates}

All the value estimates are calculated as accurately as possible; however they cannot always be regarded as being absolutely precise to the last digit shown. Similarly, the index numbers are not necessarily absolutely precise to the last digit shown. Some figures are provisional and may be revised later; this applies particularly to many of the detailed figures for the latest years.

\section{Revisions since ONS Pink Book 2007}

The current account balance is revised from 1987 onwards.

Goods - the data are revised from 2004 to reflect revised data from HM Revenue \& Customs and other data suppliers together with revised estimates of trading associated with Missing Trader Intra-Community (MTIC) VAT fraud. This includes a reassessment of data following the annual supply and use balancing process.

Services - the data are revised back to 1971. The earliest revisions result from the introduction of financial intermediation services indirectly measured (FISIM), (please see methodological notes for table 3.6). Revisions for 2004 onwards are also from a general reassessment of data following the annual supply and use balancing process. 
Revisions to 2006 additionally reflect the use of final results from the ONS's annual International Trade in Services Survey for 2006.

Income, Financial Account and IIP - investment income figures are revised back to 1971 to incorporate the counterpart to the FISIM revision to trade in services. These revisions to investment income offset those made in the trade in services account so as to have no net effect on the current account balance. Estimates for UK non-bank deposits with and loans from banks abroad are revised back to 1989 to remove the double counting of securities dealers' deposits with and loans from banks abroad. Securities dealers' deposit and loan information is collected by the ONS and is also included implicitly in the data the ONS received from the Bank for International Settlements via the Bank of England on UK non-bank deposits with and loans from banks abroad. Non-resident holdings of UK quoted shares are revised back to 1998 to incorporate corrected information from the ONS Share Ownership Survey and new information on securities dealers' custody holdings on behalf of non-residents. UK banks income payments within other investments are revised back to 2000 to incorporate additional income payments associated with repurchase agreements and stock lending activity. Other revisions include new information on portfolio investment abroad by UK securities dealers from 2005 onwards and on foreign direct investment for 2005 alone.

Current transfers - the data are revised back to 1987. These revisions to non-life insurance premiums and claims and are the result of ensuring the internal consistency of the data for UK insurance companies transaction with non-residents and are offsetting between credits and debits. Revisions from 2004 onwards also reflect the latest data from HM Treasury for transfers involving the UK Government and the latest data from annual direct investment surveys which provide estimates of taxes on investment income.

Capital transfers - the data are revised from 2004. These revisions are due to source data changes for transfers involving the UK government. Revisions also reflect the final results from the annual International Trade in Services survey for 2006.

\section{Symbols and conventions used in the tables}

\section{Rounding}

As figures have been rounded to the nearest final digit, there may be slight discrepancies between the sums of the constituent items and the totals as shown.

\section{Symbols}

The following symbols are used throughout:

.. $=$ not available

- $\quad$ = nil or less than a million

\section{References}

The internationally agreed framework for the presentation of the Balance of Payments and the National Accounts are described in the following publications:

Balance of Payments Manual (5th edition 1993), International Monetary Fund (ISBN 1-55775-339-3). www.imf.org/external/np/sta/bop/BOPman.pdf

Balance of Payments Textbook (1996), International Monetary Fund (ISBN 1-55775570-1). www.imf.org/external/np/sta/bop/BOPtex.pdf 
Balance of Payments and International Investment Position, Australia: Concepts, Sources and Methods (1998) Australian Bureau of Statistics (ISBN 0-642-25670-5). www.abs.gov.au/Ausstats/abs@.nsf/0/ 09998 F91F5A8A7BFCA25697E0018FB0A?Open

European System of Accounts (ESA 1995), Office for Official Publications of the European Communities (ISBN 92-827-7954-8)

System of National Accounts (1993), (ISBN 92-1-161352-3).

http://unstats.un.org/unsd/sna1993/introduction.asp

The United Nations Statistics Commission and the IMF Board of Directors have approved the comprehensive and parallel updating of the National Accounts and Balance of Payments manuals, in order to ensure their consistency and achieve greater harmonisation. ONS has developed the following webpage to inform users of progress and to invite their input:

www.statistics.gov.uk/about/Consultations/NA/default.asp 